\title{
ANALISIS KOMPARATIF USAHA JAMUR TIRAM COKLAT DENGAN JAMUR TIRAM PUTIH DI KECAMATAN KAPAS KABUPATEN BOJONEGORO
}

\author{
Azhari \\ Fakultas Ekonomi, Universitas Bojonegoro \\ JL. Lettu Suyitno No. 02 Bojonegoro \\ azhari1969@unigoro.ac.id
}

\begin{abstract}
ABSTRAK
Tujuan penelitian adalah untuk mengetahui pendapatan usaha jamur tiram coklat adalah lebih tinggi dibandingkan dengan jamur tiram putih di Kecamatan Kapas Kabupaten Bojonegoro dan untuk mengetahui usaha jamur tiram coklat lebih efisien dibandingkan jamur tiram putih di Kecamatan Kapas Kabupaten Bojonegoro. Hipotesis dalam penelitian ini diduga pendapatan usaha jamur tiram coklat lebih tinggi dibandingkan dengan jamur tiram putih di Kecamatan Kapas Kabupaten Bojonegoro dan diduga usaha jamur tiram coklat lebih efisien bila dibandingkan dengan jamur tiram putih di Kecamatan Kapas Kabupaten Bojonegoro.

Dilakukan penelitian di lapang jumlahnya yang relatif sedikit maka pengambilan sampel usaha jamur tiram putih dan jamur tiram coklat ini tidak peneliti lakukan, akan tetapi peneliti mengambil semua usaha jamur tiram putih dan jamur tiram coklat Kecamatan Kapas Bojonegoro adalah sebanyak 15 usaha jamur tiram putih dan 15 usaha jamur tiram coklat. Dengan demikian maka, penelitian ini dinamakan penelitian populasi karena semua masyarakat yang melakukan usaha atau budidaya jamur tiram putih dan jamur tiram coklat di Kecamatan Kapas Kabupaten Bojonegoro adalah sejumlah tersebut. Metode pengambilan responden dilakukan dengan cara metode sensus adalah mengambil seluruh populasi yang ada sebagai responden. Dari data yang diperoleh menunjukkan bahwa semua usaha jamur tiram dijadikan responden.Biaya variabel terbesar dipergunakan untuk enam bulan setiap kali produksi adalah biaya bibit, baik itu untuk usaha jamur tiram coklat maupun untuk usaha jamur tiram putih. Biaya bibit untuk jamur tiram coklat adalah Rp.18.000.000,- dan biaya bibit untuk jamur tiram putih adalah Rp. 14.490.000,- dalam satu kali produksi jamur tiram.

Sedangkan biaya variabel yang terkecil adalah biaya pembelian kapur yaitu sebesar Rp.55.000,- untuk jamu tiram putih dan Rp. 70.000,- untuk jamur tiram coklat.

Biaya tetap yang digunakan dalam penelitian ini adalah merupakan biaya penyusutan peralatan-peralatan yang digunakan di dalam proses produksi tersebut. Adapun peralatan-peralatan yang digunakan dalam proses produksi jamur tiram coklat maupun putih adalah bangunan, peralatan dan sewa lahan.
\end{abstract}

Dengan cara mengurangi rata-rata total penerimaan dan rata-rata total biaya maka dapat diperoleh rata-rata pendapatan. Rata-rata pendapatan pada usaha jamur tiram coklat adalah $R p$. 51.000 .000$, ,- dan rata-rata pendapatan pada usaha jamur tiram putih adalah Rp. 37.270.000,- Hasil uji $t$ menunjukkan bahwa $t$ hitung besarnya 20,515 sedangkan $t$ tabel $(\alpha=0,05)$ besarnya 1,711. Nilai $t$ hitung lebih besar dari t tabel, maka pendapatan usaha jamur tiram coklat (Rp. 51.000.000,-/ 6 bulan) lebih tinggi dari pendapatan usaha jamur tiram putih (Rp. 37.270.000,-/ 6 bulan) adalah nyata atau signifikan. $R / C$ Ratio pada usaha jamur tiram putih adalah besarnya 
1,63 dan R/C Ratio untuk usaha jamur tiram coklat adalah 1,81. Nilai $R / C$

Ratio usaha jamur tiram di Kecamatan Kapas Bojonegoro lebih dari satu koma dua yang berarti bahwa usaha jamur tiram putih dan coklat di Kecamatan Kapas Bojonegoro adalah efisien atau usaha jamur tiram di Kecamatan Kapas Bojonegoro adalah menguntungkan dan memberikan keuntungan yang layak.

Kata kunci : usaha, jamur tiram coklat, jamur tiram putih

\section{PENDAHULUAN}

Jamur yang disebut cendawan atau mushroom ini memiliki nilai bisnis besar yang terus meningkat dalam waktu setengah abad terakhir. Bahkan di beberapa negara merupakan salah satu komoditas andalan untuk pasar lokal dan ekspor, seperti jamur merang, jamur tiram, jamur kuping, champignon, shiitake, lingzhi, dan sebagainya.

Minat masyarakat untuk mengkonsumsi jamur terus meningkat sehingga berpengaruh terhadap permintaan jamur di pasar. Berapapun jumlah jamur yang diproduksi oleh petani selalu terjual habis oleh pasar. Namun, pasar jamur ini hanya terpusat di kota - kota besar, dikarenakan harga jamur yang relatif lebih mahal bila dibandingkan dengan sayuran lain. Harga jamur bisa dikatakan lebih stabil bila dibandingkan dengan sayuran lainnya, seperti cabai dan bawang merah.

\section{Menurut}

Direktorat

Jenderal Hortikultura

(2012) jamur tiram mempunyai beberapa jenis yaitu jamur tiram putih, jamur tiram abu-abu, jamur tiram coklat, dan jamur tiram merah. Jenis jamur yang paling banyak dibudidayakan di wilayah Indonesia adalah jamur tiram putih dan coklat selain itu rasanya yang lebih lezat masyarakat juga lebih menyukai dan mengenal jamur tiram tersebut dibandingkan dengan jenis jamur tiram yang lain. Jamur tiram putih dan coklat bisa diproduksi sepanjang tahun dalam areal yang relatif sempit. Hal ini merupakan alternatif yang cukup baik dalam rangka memanfaatkan lahan perkarangan. Budidaya jamur tiram tidak menggunakan bahan - bahan kimia atau pupuk anorganik sehingga tidak merusak lingkungan sekitar.

Dilihat dari segi teknik budidaya, jamur tiram ini dapat dibudidayakan dengan mudah 
dikarenakan indonesia mempunyai potensi wilayah yang menunjang perkembangannya. Jamur tiram putih dan coklat mempunyai kandungan gizi yang baik bagi tubuh. Jamur tiram memiliki kandungan protein yang relatif lebih tinggi dibandingkan dengan sayuran lainnya dan juga pengembangan kakao di provinsi sulawesi barat. (Abbas,Wandi,et al.2018)

Kandungan lemak pada jamur tiram putih dan coklat relatif lebih rendah dibandingkan jamur shiitake dan tauge. Sedangkan kandungan serat paling tinggi adalah jamur kuping. Jamur tiram mempunyai kandungan seratnya cukup tinggi dibandingkan jamur shitake dan jamur merang, baik untuk proses pencernaan. Oleh sebab itu mengkonsumsi jamur tiram sangat baik untuk kesehatan, karena kandungan gizinya memiliki kandungan protein tinggi, kadar lemak cukup rendah serta kandungan serat tinggi.

Dewasa ini, jamur telah menjadi bagian dari kebutuhan masyarakat sehari - hari. Tanpa adanya jamur mustahil bagi masyarakat dapat membuat roti, tempe, tape, oncom, tauco, dan obat - obatan seperti pinisilin. Beberapa jenis jamur merupakan sumber makanan setara dengan daging dan ikan yang bergizi tinggi. Jamur merupakan bahan pangan alternatif yang disukai oleh hampir semua lapisan masyarakat.

Jamur-jamur yang telah dibudidayakan dan populer atau memasyarakat sebagai makanan dan sayuran serta banyak diperdagangkan di pasar adalah jamur tiram, jamur merang, jamur champignon, jamur kuping dan jamur payung shitake. Menurut Djarijah dan Abbas (2011), menyatakan bahwa jamur tiram adalah jenis jamur kayu yang mempunyai kandungan nutrisi lebih tinggi dibandingkan dengan jenis jamur kayu lainnya. Jamur tiram mengandung protein, lemak, besi, thiamin, dan riboflavin lebih tinggi dibandingkan dengan jenis jamur yang lain. Budidaya jamur tiram dapat dikembangkan sebagai salah satu alternatif usaha untuk menambah kebutuhan 
kebutuhan gizi ataupun pendapatan keluarga. Ditinjau dari aspek biologinya, jamur tiram relatif lebih mudah dibudidayakan. Pengembangan jamur tiram tidak memerlukan lahan yang luas. Lokasi budidaya untuk jamur tiram dapat dibangun di pekarangan atau kebun-kebun di lereng pegunungan atau wilayah perbukitan yang teduh ternaungi pepohonan serta dapat pula di dalam rumah jamur (kubung) yang dibuat di sekitar rumah tinggal atau di dalam rumah. Masa produksi jamur tiram relatif lebih cepat sehingga periode dan waktu panen lebih singkat dan dapat kontinyu (Djarijah dan Abbas, 2011) dan (muhtarom, abid,et al. 2019).

Wilayah Kecamatan Kapas Bojonegoro mempunyai 21 Desa dengan mata pencaharian beragam dan salah satunya adalah melakukan budidaya jamur tiram. Diantara desa-desa tersebut, memang tidak seluruhnya desa melakukan budidaya jamur tiram, tetapi bisa dipastikan tidak kurang dari sepuluh desa, masyarakatnya melakukan budidaya jamur tiram.
Jamur tiram yang banyak dibudidayakan oleh masyarakat adalah jamur tiram putih, karena jamur tiram putih lebih awal popular bila dibandingkan dengan jamur tiram coklat yang baru meningkat popularitasnya beberapa tahun yang lalu.

Semakin lama di Kecamatan Kapas, kian banyak yang melakukan budidaya jamur tiram coklat. Namun bukan berarti yang melakukan budidaya jamur tiram putih berkurang, karena bila dilihat aspek pasarnya dan yang melakukan budidaya jamur tiram, masih terbuka lebar untuk terserap pasar. Permintaan masyarakat akan produk jamur tiram semakin beragam, karena saat ini banyak di masyarakat memanfaatkan jamur tiram menjadi produk olahan (industri hilir) seperti keripik jamur, crispy dan nugget jamur. Di wilayah lain terutama kota-kota besar, produk olahan jamur tiram ini diolah sedemikian rupa menjadi abon jamur, permen jeli jamur tiram, sate jamur dan tumis jamur tiram. Selain membidik konsumen dari masyarakat yang mengkonsumsi 
menu vegetarian, olahan jamur tiram juga bisa bermanfaat bagi masyarakat yang gemar melilih makanan sehat. Hal ini dikarenakan, kandungan gizi pada jamur tiram telah diketahui bahwa memiliki banyak manfaatnya, terutama untuk jamur tiram yang sudah umum dikonsumsi.

\section{METODE PENELITIAN}

Memilih cara dan alat pengumpulan data yang tepat sangat penting, sebab akan menentukan kualitas dari data yang dikumpulkan dan juga kualitas hasil penelitian tersebut. Untuk memperoleh data berkualitas peneliti harus menggunakannya teknik-teknik dalam pengumpulan. Selain itu dalam pengumpulan data juga dituntut adanya pengalaman pada diri peneliti serta ditunjang dengan pendidikan dan alat-alat yang memadai. Memperoleh data realible dan valid adalah tujuannya dalam pengumpulan data. Data dapat dibedakan menjadi dua yaitu data primer dan data sekunder.

1. Data primer, adalah data yang diusahakannya sendiri peneliti. Untuk memperoleh data primer peneliti harus melakukan penelitian di lapang langsung berhubungan dengan obyek yang diteliti. Data primer diambil dari responden penelitian yakni usaha jamur tiram putih dan jamur tiram coklat di Kecamatan Kapas Bojonegoro sebagai responden melalui wawancara langsung. Daftar pertanyaan disiapkan dan disusun terlebih dahulu, sehingga wawancara tidak keluar dari topik penelitian. Agar perolehan data primer valid dan akurat, interview dan survei dilakukannya secara terpisah bagi tiap responden penelitian. Dengan demikian masing-masing perorangan tidak saling terpengaruh.

2. Data sekunder yang diperoleh berdasarkan keterangan seseorang atau petugas lembaga/ instansi serta didukung dengan bahan bacaan yang berhubungan dengan topik penelitian.Keuntungan menggunakan data sekunder dalam sebuah penelitian adalah lebih murah dan lebih cepat, karena dalam pengumpulan tidak dilakukan sendiri peneliti 
yang berarti bahwa data sekunder yang diperoleh peneliti sudah merupakan susunan data rapi dan sistematis. Mencari teori, konsep generalisasi yang dapat dijadikan landasan teoritas bagi penelitian yang akan dilakukan itu. Landasan itu perlu ditegakkan agar penelitian itu mempunyai dasar yang kokoh untuk mendapatkan informasi mengenai berbagai hal diatas maka peneliti harus menelaah kepustakaan, memang umumnya lebih dari lima puluh persen kegiatan seluruh proses penelitian adalah membaca karena itu sumber bacaan merupakan penunjang penelitian.

\section{Analisis Pendapatan}

Digunakan rumus Soekartawi, (2007), sebagai berikut :

II = TR - TC

Keterangan :

II = Pendapatan (Rp)

$\mathrm{TR}=$ Total Revenue $(\mathrm{Rp})$

$\mathrm{TC}=$ Total Cost $(\mathrm{Rp})$

Analisis statistik

menguji perbandingan

pendapatannya usaha jamur tiram putih dan usaha jamur tiram coklat menggunakan uji $\mathrm{t}$ (t-test). Adapun tahapan dalam pengujiannya sebagai berikut :

1) Formulasi $\mathrm{H}_{0}$ dan $\mathrm{H}_{1}$ $\mathrm{H}_{0}: \mu_{1}=\mu_{2}$

$\mathrm{H}_{1}: \mu_{1} \neq \mu_{2}$

Keterangan :

$\mu_{1}$ : Pendapatan usaha jamur tiram coklat

$\mu_{2}$ : Pendapatan usaha jamur tiram putih

$\mathrm{H}_{0}$ : Pendapatan usaha jamur tiram coklat $=$ usaha jamur tiram putih

$\mathrm{H}_{1}$ : Pendapatan usaha jamur tiram coklat > usaha jamur tiram putih.

2) Menentukan level of significance $(\alpha)$ ditentukan nilai $\alpha=5 \%$

3) Menentukan kriteria pengujian

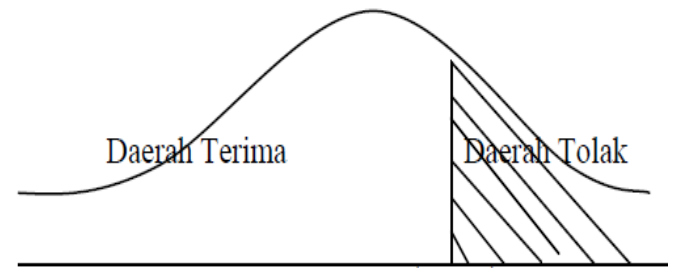


Gambar 1. Kriteria Pengujian efisiensi t-tabel

$\mathrm{H}_{0}$ diterima apabila : $\mathrm{t}$ hitung $\leq \mathrm{t}$ tabel $\mathrm{H}_{1}$ ditolak apabila : $\mathrm{t}$ hitung $>\mathrm{t}$ tabel

4) Perhitungan nilai t hitung

(Husien Umar, 2008)

$$
\mathrm{t}=\frac{\left[\overline{\mathrm{X}_{1}}-\overline{\mathrm{X}_{2}}\right]}{\sqrt{\frac{\left(\mathrm{n}_{1}-1\right) \mathrm{Sd}_{1}^{2}+\left(\mathrm{n}_{2}-1\right) \mathrm{Sd}_{2}^{2}}{\left(\mathrm{n}_{1}+\mathrm{n}_{2}\right)-2}\left[\frac{1}{\mathrm{n}_{1}}+\frac{1}{\mathrm{n}_{2}}\right]}}
$$

Keterangan :

$$
\mathrm{X}_{1}=\text { Rata-rata pendapatan }
$$

usaha jamur tiram coklat (Rp)

$$
\mathrm{X}_{2} \text { = Rata-rata pendapatan }
$$

usaha jamur tiram putih ( $R p)$

$$
\mathrm{S}_{1}{ }^{2}=\text { Varian pendapatan }
$$

usaha jamur tiram coklat

$$
\mathrm{S}_{2}{ }^{2}=\text { Varian pendapatan }
$$

usaha jamur tiram putih

$$
\mathrm{n}_{1}=\text { Jumlah petani sampel }
$$

usaha jamur tiram coklat

$$
\mathrm{n}_{2}=\text { Jumlah petani sampel }
$$

usaha jamur tiram putih

Dengan kriteria sebagai berikut :

Jika $\mathrm{t}_{\text {hitung }}>\mathrm{t}$ tabel maka hipotesis Ho ditolak

Jika $\mathrm{t}_{\text {hitung }} \leq \mathrm{t}$ tabel maka hipotesis Ho diterima

\section{Analisis Efisiensi Usaha}

Perhitungan Efisiensi Usaha

(Muhtarom, Abid.2018)

$$
\text { Efisiensi Usahatan } i=\frac{R}{C}
$$

Keterangan :

$\mathrm{R}$ : Besarnya penerimaan usaha jamur tiram coklat atau putih $(\mathrm{Rp})$

C : Besarnya biaya yang dikeluarkan usaha jamur tiram coklat atau putih (Rp) Analisis ini adalah digunakan untuk menguji perbandingan efisiensi antara usaha jamur tiram coklat dan jamur tiram putih menggunakan uji $\mathrm{t}$ (t-test). Tahap pengujian sebagai berikut :

1) Formulasi $\mathrm{H}_{0}$ dan $\mathrm{H}_{1}$

$$
\begin{aligned}
& \mathrm{H}_{0}: \varepsilon_{1}=\varepsilon_{2} \\
& \mathrm{H}_{1}: \varepsilon_{1}>\varepsilon_{2}
\end{aligned}
$$

Keterangan :

$\varepsilon_{1}$ : Efisiensi usaha jamur tiram coklat

$\varepsilon_{2}$ : Efisiensi usaha jamur tiram putih

$$
\begin{array}{r}
\mathrm{H}_{0} \text { : Efisiensi usaha jamur } \\
\text { tiram coklat }=\text { efisiensi }
\end{array}
$$


usaha jamur tiram putih

$\mathrm{H}_{1}$ : Efisiensi usaha jamur tiram coklat $>$ efisiensi usaha jamur tiram putih.

2) Menentukan level of significance $(\alpha)$ penelitian ini ditentukan nilai $\alpha=5 \%$

3) Menentukan kriteria pengujian (Husien Umar, 2008)

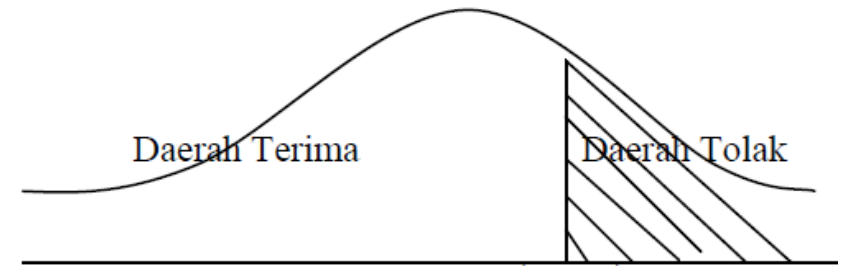

t-tabel

Gambar 2. Kriteria Pengujian efisiensi t-tabel

Jika $\mathrm{t}_{\text {hitung }}>\mathrm{t}$ tabel maka hipotesis Ho ditolak

Jika $t_{\text {hitung }} \leq \mathrm{t}_{\text {tabel }}$ maka hipotesis Ho diterima

\section{HASIL PENELITIAN DAN PEMBAHASAN}

Biaya usaha jamur tiram yang dikeluarkan adalah seluruh biaya yang telah dikeluarkan dalam menjalankan usaha jamur tiram. Biaya total yang dikeluarkan terdiri atas biaya tunai dan biaya diperhitungkan (biaya tidak tunai). Biaya tunai merupakan biaya langsung yang dikeluarkan oleh petani dalam bentuk rupiah dalam menjalankan kegiatan usaha pertaniannya seperti, biaya pembelian bibit, pembelian bahan baku, pendukung dan upah tenaga kerja.

Biaya yang diperhitungkan (biaya tidak tunai) digunakan untuk menghitung berapa sebenarnya pendapatan kerja dari petani, modal, dan menilai kerja keluarga. Tenaga kerja keluarga dinilai berdasarkan upah yang berlaku. Biaya penyusutan peralatan, bangunan dan sewa lahan milik sendiri juga dapat dimasukkan ke dalam biaya diperhitungkan.

\section{a. Biaya}

Biaya tunai merupakan biaya yang harus dikeluarkan dalam bentuk tunai. Biaya tunai dalam penelitian ini meliputi biaya pembelian bibit, serbuk kayu, dedak, kapur, gipsum, plastik media, karet gelang, kayu bakar, cincin bambu, kertas, spirtus, alkohol, gaji 
tenaga kerja baglog, bonus lembur tenaga kerja baglog, biaya transportasi baglog, biaya listrik air, biaya paket pembangunan kumbung budidaya, plastik kemasan jamur, transportasi pemasaran jamur, gaji tenaga kerja jamur, dan bagi hasil. Informasi mengenai keseluruhan komponen biaya tunai pada masing-masing produksi disajikan pada berikut ini :

Tabel 1

Rata-rata Komponen Biaya Usaha Jamur Tiram Putih Kecamatan Kapas Bojonegoro

\begin{tabular}{|c|l|c|r|r|r|}
\hline No & \multicolumn{1}{|c|}{$\begin{array}{c}\text { Komponen } \\
\text { Biaya }\end{array}$} & Satuan & Kebutuhan & $\begin{array}{c}\text { Harga } \\
\text { (Rp) }\end{array}$ & $\begin{array}{c}\text { Jumlah } \\
\text { (Rp) }\end{array}$ \\
\hline 1 & Bibit & botol & 204 & 70.000 & 14.490 .000 \\
2 & Serbuk kayu & karung & 1.050 & 5.000 & 5.250 .000 \\
3 & Dedak & $\mathrm{kg}$ & 600 & 2.000 & 1.200 .000 \\
4 & Kapur & $\mathrm{kg}$ & 11 & 5.000 & 55.000 \\
5 & Gipsum & $\mathrm{kg}$ & 600 & 6.000 & 3.600 .000 \\
6 & Plastik Media & $\mathrm{Rol}$ & 22 & 50.000 & 1.100 .000 \\
7 & Karet Gelang & $\mathrm{kg}$ & 10 & 60.000 & 600.000 \\
8 & Kayu bakar & mobil & 4 & 250.000 & 1.000 .000 \\
9 & Cincin bamboo & ring & 6.000 & 50 & 3.000 .000 \\
10 & Kertas & $\mathrm{kg}$ & 80 & 1500 & 120.000 \\
11 & Spirtus & 1 & 30 & 8500 & 255.000 \\
12 & Alkohol & 1 & 10 & 16.000 & 160.000 \\
13 & Gaji TK 6 bulan & orang & 4 & 6.000 .000 & 24.000 .000 \\
14 & Listrik air 6 bulan & unit & 1 & 600.000 & 600.000 \\
15 & Lain-lain & - & - & - & 300.000 \\
16 & Bangunan & - & - & - & 1.000 .000 \\
17 & Peralatan & - & - & - & 500.000 \\
18 & Sewa lahan & - & - & - & 1.500 .000 \\
\hline \multicolumn{4}{|l|}{ Jumlah } \\
\hline
\end{tabular}

Sumber : data Primer diolah, 2018

Berdasarkan tabel diatas biaya variabel yang terbesar dipergunakan untuk enam bulan tiap kali produksi adalah biaya tenaga kerja yaitu Rp. 24.000.000,-. Bersarnya biaya tenaga kerja tersebut disebabkan karena jumlah tenaga kerja yang digunakan adalah 4 orang.
Kemudian berikutnya biaya bibit adalah Rp. 14.490.000,dan setelah itu adalah biaya serbuk kayu yaitu Rp.5.250.000,- setiap enam bulan. Sedangkan biaya variabel yang terkecil adalah biaya kapur yaitu sebanyak Rp.55.000,Berdasarkan pada tabel itu pula, 
dapatlah dijelaskan bahwa analisis usaha untuk biaya variabel yang tercantum merupakan analisis usaha jamur
Tiram putih, sedangkan analisis usaha untuk biaya variabel jamur tiram coklat dapat diuraikan pada tabel berikut ini.

Tabel 2

Rata-rata Komponen Biaya Usaha Jamur Tiram Coklat Kecamatan Kapas Bojonegoro

\begin{tabular}{|c|c|c|c|c|c|}
\hline No & $\begin{array}{c}\text { Komponen } \\
\text { Biaya }\end{array}$ & Satuan & Kebutuhan & $\begin{array}{l}\text { Harga } \\
\text { (Rp) }\end{array}$ & $\begin{array}{c}\text { Jumlah } \\
\text { (Rp) }\end{array}$ \\
\hline 1 & Bibit & botol & 200 & 90.000 & 18.000 .000 \\
\hline 2 & Serbuk kayu & karung & 1.065 & 5.000 & 5.325 .000 \\
\hline 3 & Dedak & $\mathrm{kg}$ & 620 & 2.000 & 1.240 .000 \\
\hline 4 & Kapur & $\mathrm{kg}$ & 14 & 5.000 & 70.000 \\
\hline 5 & Gipsum & $\mathrm{kg}$ & 610 & 6.000 & 3.660 .000 \\
\hline 6 & Plastik Media & Rol & 25 & 50.000 & 1.150 .000 \\
\hline 7 & Karet Gelang & $\mathrm{kg}$ & 12 & 60.000 & 720.000 \\
\hline 8 & Kayu bakar & mobil & 4 & 250.000 & 1.000 .000 \\
\hline 9 & Cincin bamboo & ring & 6.000 & 50 & 3.000 .000 \\
\hline 10 & Kertas & $\mathrm{kg}$ & 100 & 1500 & 150.000 \\
\hline 11 & Spirtus & 1 & 36 & 8500 & 306.000 \\
\hline 12 & Alkohol & 1 & 10 & 16.000 & 160.000 \\
\hline 13 & Gaji TK 6 bulan & orang & 4 & 6.000 .000 & 24.000 .000 \\
\hline 14 & Listrik air 6 bulan & unit & 1 & 850.000 & 850.000 \\
\hline 15 & Lain-lain & - & - & - & 369.000 \\
\hline 16 & Bangunan & - & - & - & 1.000 .000 \\
\hline 17 & Peralatan & - & - & - & 500.000 \\
\hline 18 & Sewa lahan & - & - & - & 1.500 .000 \\
\hline \multicolumn{5}{|c|}{ Jumlah } & 63.000.000 \\
\hline
\end{tabular}

Sumber : data Primer diolah, 2018

Biaya tetap yang

digunakan dalam penelitian adalah merupakan biaya penyusutan alat-alat yang digunakan dalam proses produksi. Adapun alat-alat yang digunakan dalam proses produksi ini adalah bangunan, peralatan dan sewa lahan. Penggunaan peralatan produksi tersebut diatas perlu dibebankan biaya penyusutan karena bangunan dan peralatan serta sewa lahan digunakan untuk proses produksi. Menghitung tarif penyusutan bangunan dan peralatan pada proses produksi Jamur Tiram adalah dengan menggunakan metode garis lurus sebagai berikut (Horngren, 2008) : 
Nilai Perolehan - Nilai Sisa

Tarif Penyusutan $=$

Umur Ekonomis

Sedangkan lahan walaupun ini milik sendiri, namun hal ini dibebankan sebagai sewa lahan. Biaya tetap adalah biaya yang besarnya tidak tergantung pada sedikit banyaknya produk yang diproduksi, dan relatif bersifat tetap dalam kurun waktu lebih dari satu tahun. Pada agribisnis budidaya jamur tiram, biaya yang dapat dialokasikan sebagai

Tabel 3

Rata-rata Penerimaan Usaha Jamur Tiram di Kecamatan Kapas Bojonegoro

biaya tetap adalah bangunan, peralatan dan sewa lahan. Biaya tetap yang terbesar dalam penelitian ini adalah sewa lahan.

\section{b. Penerimaan}

Penerimaan usaha

budidaya jamur tiram putih dan coklat di Kecamatan Kapas

Bojonegoro ini adalah perkalian antara total produk terjual dengan harga per satuan produk. Penerimaan dari usaha budidaya jamur tiram di Kecamatan Kapas Bojonegoro dapat dilihat pada tabel berikut ini.

Bojonegoro selama enam bulan adalah sebanyak $7.600 \mathrm{~kg}$. Harga rata-rata jamur tiram putih di Kecamatan Kapas

\begin{tabular}{|c|c|c|c|c|}
\hline $\begin{array}{c}\text { Jamur } \\
\text { Tiram }\end{array}$ & $\begin{array}{c}\text { Rata-rata } \\
\text { Produksi } \\
(\mathbf{k g})\end{array}$ & $\begin{array}{c}\text { Harga Per kg } \\
(\mathbf{R p})\end{array}$ & $\begin{array}{c}\text { PenerimaaBojonegoro adalah Rp 12.000,- } \\
(\mathbf{R p})\end{array}$ \\
\hline Putih & 8.000 & 12.000 & $96.000 .009_{\text {put }}$ & harga rata-rata jamur tiram \\
\hline Coklat & 7.600 & 15.000 & 114.000 .00 Bojonegoro adalah Rp 15.000,-.
\end{tabular}

Sumber : data primer diolah, 2018

Berdasarkan tabel

diatas, maka dapat diketahui rata-rata produksi usaha jamur tiram putih di Kecamatan Kapas Bojonegoro selama enam bulan adalah sebanyak $8.000 \mathrm{~kg}$ dan rata-rata produksi usaha jamur tiram putih di Kecamatan Kapas
Dari rata-rata produksi yang dapat terjual dan harga rataratanya maka akan dihasilkan penerimaan. Besarnya rata-rata penerimaan yang diperoleh dari usaha jamur tiram putih di Kecamatan Kapas Bojonegoro selama enam bulan yaitu sebesar Rp 96.000.000,- dan besarnya 
rata-rata penerimaan yang diperoleh dari usaha jamur tiram coklat di Kecamatan Kapas Bojonegoro selama enam bulan yaitu sebesar Rp 114.000.000,-

c. Pendapatan

Pendapatan yang
diperoleh usaha jamur tiram
putih dan coklat adalah selisih
antara penerimaan dari hasil
penjualan Jamur Tiram putih
dan coklat dengan biaya
totalnya. Perbedaan keuntungan
yang dapat diperoleh masing-
masing produsen dapat
dipengaruhi
penerimaan total dan besarnya
biaya total dikeluarkan. Untuk
mengetahui pendapatan usaha
jamur tiram putih dan coklat di
Kecamatan Kapas Bojonegoro
dapat dilihat pada tabel berikut
ini.

Tabel 4

Rata-rata Pendapatan Usaha Jamur Tiram di Kecamatan Kapas Bojonegoro
Berdasarkan tabel

diatas, dengan cara mengurangi total penerimaan dan total biaya maka dapat diketahui besar ratarata pendapatan usaha jamur tiram putih di Kecamatan Kapas Bojonegoro diperoleh sebesar Rp. 37.270.000,- dan rata-rata pendapatan usaha jamur tiram coklat di Kecamatan Kapas Bojonegoro diperoleh sebesar Rp. $\quad 51.000 .000$,-setiap pengusaha dalam enam bulan.

$$
\text { Berdasarkan tabel }
$$

diatas diketahui pendapatan usaha jamur tiram coklat adalah lebih tinggi dari pendapatan usaha jamur tiram putih, berarti hipotesis yang menyatakan diduga pendapatan usaha jamur tiram coklat adalah lebih tinggi dibandingkan dengan jamur tiram putih di Kecamatan Kapas Bojonegoro adalah terbukti karena nilai pendapatan sebesar Rp. 51.000.000,- adalah lebih tinggi dari pada Rp.

\begin{tabular}{|c|c|c|c|c|}
\hline No & Uraian & $\begin{array}{c}\text { Jamur Tiram } \\
\text { Putih (Rp) }\end{array}$ & $\begin{array}{l}\text { Jamur3Г1raño.000,-. } \\
\text { Coklat (Rp) }\end{array}$ & \\
\hline 1 & Total Penerimaan & 96.000 .000 & 114doodedieiensi & \\
\hline 2 & Total Biaya & 58.730 .000 & 63.000 .000 & \\
\hline 3 & Total Pendapatan & 37.270 .000 & 51.000 .000 & merupakan \\
\hline
\end{tabular}
perbandingan penerimaan yang diperoleh setiap proses produksi 
( enam bulan) atau dengan biaya yang telah dikeluarkan oleh pelaku usaha jamur tiram putih dan coklat di Kecamatan Kapas Bojonegoro. Rata-rata efisiensi dari usaha jamur tiram putih dan coklat di Kecamatan Kapas Bojonegoro dapat dilihat tabel berikut ini :

\section{Tabel 5}

Rata-rata Efisiensi Usaha Jamur Tiram di Kecamatan Kapas Bojonegoro

\begin{tabular}{|l|l|l|c|}
\hline $\begin{array}{c}\text { N } \\
\mathbf{o}\end{array}$ & $\begin{array}{c}\text { Uraia } \\
\mathbf{n}\end{array}$ & $\begin{array}{c}\text { Jamur } \\
\text { Tiram } \\
\text { Putih }\end{array}$ & $\begin{array}{c}\text { Jamur } \\
\text { Tiram } \\
\text { Coklat }\end{array}$ \\
\hline 1. & Peneri & 96.00 & 114.0 \\
2. & maan & 0.000 & 00.00 \\
3. & Biaya & 58.73 & 0 \\
& Efisie & 0.000 & 63.00 \\
& nsi & 1.63 & 0.000 \\
& & & 1.81 \\
\hline
\end{tabular}

Sumber : data primer diolah, 2018

$$
\text { Berdasarkan tabel }
$$

diatas, maka R/C Ratio usaha jamur tiram putih di Kecamatan Kapas Bojonegoro adalah besarnya 1,63. R/C Ratio usaha jamur tiram coklat di Kecamatan Kapas Bojonegoro adalah besarnya 1,81 yang berarti bahwa usaha jamur tiram di Kecamatan Kapas Bojonegoro adalah efisien atau menguntungkan dan memberikan keuntungan yang layak. Nilai R/C 1,63 dan R/C 1,81 yang berarti bahwa dengan biaya inputnya yakni sebesar Rp.1,00 pada usaha jamur tiram putih di Kecamatan Kapas Bojonegoro akan memberikan penerimaan yaitu sebesar Rp.1,63 dan dengan biaya inputnya sebesar Rp.1,00 pada usaha jamur tiram coklat di Kecamatan Kapas Bojonegoro akan memberi penerimaan yaitu sebesar Rp.1,81.

Berdasarkan tabel diatas, diketahui efisiensi usaha jamur tiram coklat adalah efisien daripada efisiensi usaha jamur tiram putih, berarti hipotesis yang menyatakan diduga efisiensi usaha jamur tiram coklat adalah lebih efisien bila dibandingkan dengan efsiensi usaha jamur tiram putih di Kecamatan Kapas Bojonegoro adalah terbukti karena nilai efisiensi 1,81 adalah lebih tinggi dari pada efisiensi 1,63.

Biaya variabel terbesar dipergunakan untuk enam bulan setiap kali produksi adalah biaya 
bibit, baik itu untuk usaha jamur tiram coklat maupun untuk usaha jamur tiram putih. Biaya bibit untuk jamur tiram coklat adalah Rp.18.000.000,- dan biaya bibit untuk jamur tiram putih adalah Rp. 14.490.000,- dalam satu kali produksi jamur tiram.

Sedangkan biaya variabel yang terkecil adalah biaya pembelian kapur yaitu sebesar Rp.55.000,- untuk jamu tiram putih dan Rp. 70.000,- untuk jamu tiram coklat. Biaya tetap yang digunakan dalam penelitian ini adalah merupakan biaya penyusutan peralatan-peralatan yang digunakan di dalam proses produksi tersebut. Adapun peralatan-peralatan yang digunakan dalam proses produksi jamur tiram coklat maupun putih adalah bangunan, peralatan dan sewa lahan.

Dengan cara mengurangi rata-rata total penerimaan dan ratarata total biaya maka dapat diperoleh rata-rata pendapatan. Rata-rata pendapatan pada usaha jamur tiram coklat adalah Rp. 51.000 .000 ,- dan rata-rata pendapatan pada usaha jamur tiram putih adalah Rp. 37.270.000,Hasil uji $\mathrm{t}$ menunjukkan bahwa $\mathrm{t}$ hitung besarnya 20,515 sedangkan t tabel $(\alpha=0,05)$ besarnya 1,711 . Nilai $\mathrm{t}$ hitung lebih besar dari $\mathrm{t}$ tabel, maka pendapatan usaha jamur tiram coklat (Rp. 51.000.000,-/ 6 bulan) lebih tinggi dari pendapatan usaha jamur tiram putih (Rp. 37.270.000,-/ 6 bulan) adalah nyata atau signifikan.

Hasil dari uji beda rata-rata pendapatan usaha jamur tiram tersebut dapat dilihat gambar berikut ini.

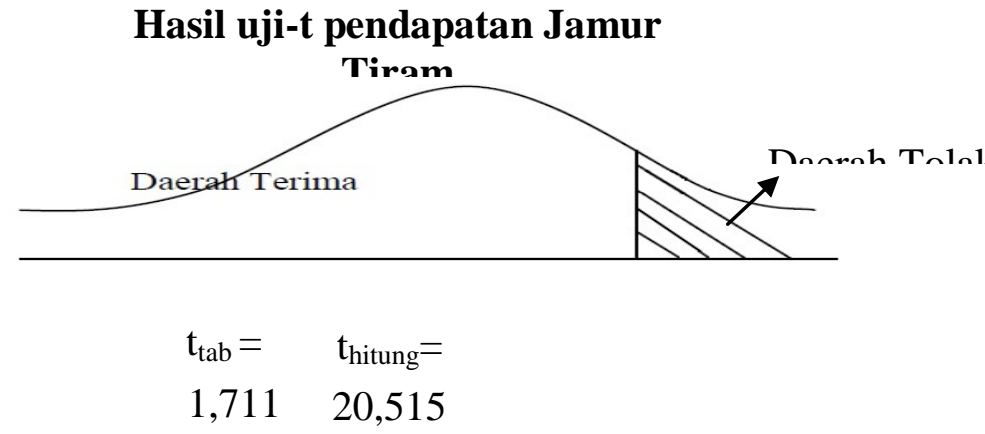

\section{Gambar 3 : Hasil uji-t Pendapatan Jamur Tiram}

R/C Ratio pada usaha jamur tiram putih adalah besarnya 1,63 dan R/C Ratio untuk usaha jamur tiram coklat adalah 1,81 . Nilai R/C Ratio usaha jamur tiram di Kecamatan Kapas Bojonegoro lebih dari satu koma dua yang berarti bahwa usaha jamur tiram 
putih dan coklat di Kecamatan Kapas Bojonegoro adalah efisien atau usaha jamur tiram di Kecamatan Kapas Bojonegoro adalah menguntungkan dan memberikan keuntungan yang layak.

Hasil uji $t$ menunjukkan bahwa $t$ hitung besarnya 28,250, sedang $\mathrm{t}$ tabel $(\alpha=0,05)$ besarnya 1,711. Nilai $t$ hitung adalah lebih besar dari pada $t_{\text {tabel, }}$ maka usaha jamur tiram coklat $(1,81)$ adalah lebih efisien daripada usaha jamur tiram putih $(1,63)$ adalah signifikan atau nyata. Hasil uji beda rata-rata efisiensi usaha jamur tiram tersebut dapat dilihat gambar berikut ini.

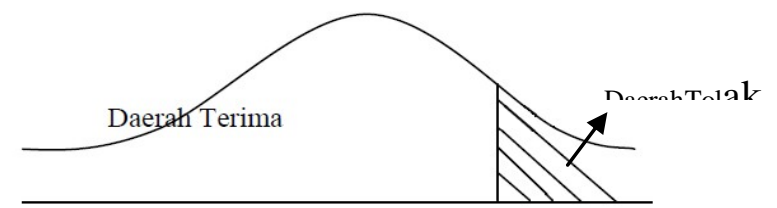

$\mathrm{t}_{\mathrm{tab}}=\quad \mathrm{t}_{\text {hitung }}=$

$1,711 \quad 28,250$

Gambar 4: Hasil uji-t Efisiensi Jamur Tiram

\section{KESIMPULAN}

Dari hasil penelitian ini tentang analisis komparatif usaha jamur tiram coklat dengan jamur tiram putih di Kecamatan Kapas
Kabupaten Bojonegoro kesimpulan yang dapat diambil yaitu :

a. Biaya variabel terbesar dipergunakan untuk enam bulan setiap kali produksi adalah biaya bibit, baik itu untuk usaha jamur tiram coklat maupun untuk usaha jamur tiram putih. Biaya bibit untuk jamur tiram coklat adalah Rp.18.000.000,- dan biaya bibit untuk jamur tiram putih adalah Rp. 14.490.000,dalam satu kali produksi jamur tiram.

b. Biaya variabel terkecil adalah biaya pembelian kapur yaitu sebesar Rp.55.000,- untuk jamu tiram putih dan Rp. 70.000,untuk jamu tiram coklat. Biaya tetap yang digunakan dalam penelitian ini adalah merupakan biaya penyusutan peralatanperalatan yang digunakan di dalam proses produksi tersebut. Adapun peralatan-peralatan yang digunakan dalam proses produksi jamur tiram coklat maupun putih adalah bangunan, peralatan dan sewa lahan.

c. Rata-rata pendapatan usaha jamur tiram coklat adalah $\mathrm{Rp}$. 51.000 .000 ,- dan rata-rata 
pendapatan usaha jamur tiram putih adalah Rp. 37.270.000,Hasil uji t menunjukkan bahwa t hitung besarnya 20,515 sedangkan $\mathrm{t}$ tabel $(\alpha=0,05)$ besarnya 1,711 . Nilai $\mathrm{t}$ hitung lebih besar $\mathrm{t}$ tabel, maka pendapatan usaha jamur tiram coklat (Rp. 51.000.000,-/ 6 bulan) lebih tinggi dari pendapatan usaha jamur tiram putih (Rp. 37.270.000,-/ 6 bulan) adalah nyata atau signifikan.

d. R/C Ratio pada usaha jamur tiram putih adalah besarnya 1,63 dan R/C Ratio untuk usaha jamur tiram coklat adalah 1,81. Nilai R/C Ratio usaha jamur tiram di Kecamatan Kapas Bojonegoro lebih dari satu koma dua yang berarti bahwa usaha jamur tiram putih dan coklat di Kecamatan Kapas Bojonegoro adalah efisien atau usaha jamur tiram di Kecamatan Kapas Bojonegoro adalah menguntungkan dan memberikan keuntungan yang layak.

e. Hasil uji t menunjukkan bahwa $\mathrm{t}$ hitung besarnya 28,250 , sedang $\mathrm{t}$ tabel $(\alpha=0,05)$ besarnya 1,711 .
Nilai $t$ hitung adalah lebih besar dari pada $t_{\text {tabel, maka usaha }}$ jamur tiram coklat $(1,81)$ adalah lebih efisien daripada usaha jamur tiram putih $(1,63)$ adalah signifikan

\section{DAFTAR PUSTAKA}
Abbas, wandi,et al.2018). Pemanfaatan bantuan luar negeri dalam peningkatan ekonomi kerakyatan tani kakao di provinsi sulawesi barat (studi program swisscontact periode 2013-2018).
Http://jurnalekonomi. unisla.ac.id/index.php /jpim/article/view/147
Anonymous, 2012, Jamur Tiram, DirJen Bina Produksi Hortikultura , Bogor
Anonymous, 2010, Jamur Tiram, Redaksi Trubus, Jakarta
Arifin 2010, Keuangan Pertanian dan Pembiayaan Agribisnis, Gramedia Jakarta
Cahyana, 2009, Jamur Tiram Pembibitan dan Analisis Usaha Penebar Swadaya Jakarta
Darmawan, 2009. Agriculture Policy Jurnal Ekonomi Pembagunan, Vol. XV Bogor. 
Djarijah, Marlina dan Abbas, 2011, Budidaya

Jamur Tiram Yogyakarta, Kanisius.

Grigg ,2008, Study in Agricultural Development.

J.W.Arrowsmith LTD. Bristol.

Hadisapoetra, 2008

Pembangunan

Pertanian. Dept. EPFP. UGM.

Yogyakarta.

Hanafi, Mamduh, 2008 Manajemen

Keuangan.

Yogyakarta: BPFE.

Husein Umar. 2008. Metode Penelitian, Jakarta: PT Raja Grafindo Persada

Irawan, 2009. Dasar-dasar Perkreditan, Yogyakarta : PT Gramedia Pustaka Utama.

Iskandar, 2008, Sukses budidaya Jamur Tiram, Penerbit Alfabeta Bandung

Kuswadi, 2005, Analisa Keekonomian Proyek, Penerbit Andy Ofset Jogyakarta

Mardikanto, 2009. Bunga Rampai

Pembangunan

Pertanian Penerbit Hapsara Solo.

Meiganati, 2012 Analisis Finansial Usaha
Jamur Tiram, IPB, Bogor

Mubyarto, 2008, Pengantar Ekonomi Pertanian, LP3ES, Jakarta

Mulyana 2009, Penyuluhan Pertanian. Penerbit Kanisius, Yogyakarta

Muhtarom,Abid, et al.2019, he Impact Of Sundaries To Improve Production And Welfare (Case study Cabai Sundari Innovation Desa Lembor District Brondong Lamongan District East Java Province). http://mediatrend.trun ojoyo.ac.id/mediatren d/article/view/4370

Muhtarom, Abid.2018. Subsisdi of fertilizers, government expenditure, level of education, ratio of range and land for agricultural production. http://journal.trunojoy o.ac.id/mediatrend/art icle/view/3382

Raharjo, 2009. Transformasi Pertanian dan Kesempatan Kerja. UI Press, Jakarta.

Ravianto, 2009. Kinerja dan Pengembangan Bisnis Group Gramedia Jakarta

Sadono Sukirno, 2008 Ekonomi Pembangunan, Penerbit LPFE- UI, Jakarta. 
Samadi, Budi. 2007. Analisis Agribisnis. Yogyakarta Kanisius.

Soekartawi. 2007. Prinsip Dasar Ekonomi Pertanian Raja Grafindo Persada. Jakarta.

Surakhmad, 2009. Pengantar Penelitian Ilmiah, Tarsito. Bandung.

Sutanto Rahmad, 2009, Penerapan Pertanian Organik. Penerbit Kanisius. Yogyakarta.
Sutomo, 2007. Ekonomi Sumberdaya, ebelas Maret University Press Surakarta

Syahyuti, $2008 \quad$ Strategi Pengembangan Kemandirian Pedesaan, PPSEP, Bogor

Tarigan, 2009, Perencanaan dan Pengelolaan Usaha. Penebar Swadaya, Jakarta.

Wati, R, 2008. Agribisnis Jamur Tiram Mandiri, DirJen Produksi Hortikultura, Bogor 